to cross the boundary to category 1 or more pneumoconiosis. This is in fact what happened and it is shown by the greater proportion who developed pneumoconiosis (table II) and the separation between the lines in fig 1 . Nevertheless, the similarity of the dose-response curves shown in fig 2 shows that the presence or absence of sputum had no effect on the attack rate of pneumoconiosis.

The implications of a possible interaction between bronchitis and pneumoconiosis were discussed in detail by Davies. ${ }^{1}$ For many years there has been controversy over the question of disability and abnormalities of respiratory function in men with pneumoconiosis. Most workers have found little difference in the results of simple function tests $\left(\mathrm{FEV}_{1}, \mathrm{FVC}\right)$ between miners with normal radiographs and those with simple pneumoconiosis. ${ }^{21}{ }^{22}$ Higgins et al ${ }^{15}$ even reported that miners without pneumoconiosis had, on average, more impairment of respiratory function than those with early simple pneumoconiosis. Davies ${ }^{1}$ considered that simple pneumoconiosis could cause disability and he suggested that the reason why epidemiologists were unable to show the true extent of this might be because bronchitis offered some protection against pneumoconiosis. Since bronchitis is one of the diseases associated with airways obstruction, there was little difference between the results of pulmonary function tests among groups of miners with or without pneumoconiosis. One group was disabled by bronchitis and the other by pneumoconiosis.

Our results do not support this hypothesis. They are compatible with a simple model in which dust exposure in the mining industry may cause pneumoconiosis, bronchitis, or both. There is no suggestion that mucus hypersecretion offers any protection against simple pneumoconiosis of coalworkers. The possibility that airflow obstruction, irrespective of mucus hypersecretion, could have a protective action cannot be excluded. An analysis of this specific problem will be made as soon as adequate data have been accumulated in the epidemiological research programme. It is unlikely that airways obstruction will turn out to have a different effect from hypersecretion of mucus since those men in the present survey with the symptoms of chronic bronchitis probably included many who also had impaired ventilatory capacity.

\section{References}

${ }^{1}$ Davies, D, British Medical fournal, 1974, 1, 652

${ }^{2}$ Rogan, J M, et al, British Medical fournal, 1961, 1, 1337.

${ }^{3}$ Fay, J W J, and Rae, S, Annals of Occupational Hygiene, 1959, 1, 149.

4 Rogan, J M, Rae, S, and Walton, W H, in Inhaled Particles and Vapours II, ed C N Davies, p 493. Oxford, Pergamon Press, 1967.

5 Jacobsen, M, et al, Nature, 1970, 227, 445.

6 Rae, S, Walker, D D, and Attfield, M D, in Inhaled Particles III, ed W H Walton, p 883. Old Woking, Unwin, 1971.

'Rogan, J M, et al, British fournal of Industrial Medicine, 1973, 30, 217.

8 International Labour Office, Occupational Safety and Health, 1959, 9, 63.

${ }^{2}$ International Labour Office, International Classification of Radiographs of Pneumoconiosis, (Revised, 1968). Geneva, International Labour Office, 1970.

${ }^{10}$ Dodgson, J, et al, in Inhaled Particles III, ed W H Walton, p 757. Old Woking, Unwin, 1971.

${ }^{11}$ Haldane, J S, Transactions of the Institute of Mining Engineers, 1918, 60, 264

${ }^{12}$ Haldane, J S, Transactions of the Institute of Mining Engineers, 1931, 80, 415.

${ }^{13}$ Fisher, S W, Transactions of the Institute of Mining Engineers, 1935, 88, 377.

${ }^{14}$ Hart, P D'arcy, and Aslett, E A, Chronic Pulmonary Disease in South Wales Coalminers, Special Report Series No 243. London, Medical Research Council, 1942.

${ }^{15}$ Higgins, I T T, et al, British Medical fournal, 1956, 2, 904.

${ }^{16}$ Van Mechelen, V, and Gielen, E, cited in fournal of the American Medical Association, 1957, 164, 1142

17 Gough, J, in Modern Trends in Pathology, ed D H Collins, p 286. London, Butterworth, 1959.

${ }_{18}$ Thomson, M L, and Pavia, D, Lancet, 1974, 1, 225.

19 Lippmann, M, Albert, R E, and Peterson, H T, in Inhaled Particles III, ed W $\mathrm{H}$ Walton, $\mathrm{p} 105$. Old Woking, Unwin, 1971.

${ }^{20}$ Sanchis, J, et al, in Inhaled Particles III, ed W H Walton, p 183. Old Woking, Unwin, 1971.

${ }^{21}$ Ashford, J R, et al, American Review of Respiratory Diseases, 1968, 97, 810 ${ }^{22}$ Cochrane, A L, Proceedings of the Royal Society of Medicine, 1976, 69, 12.

\title{
Prevalence of severe growth hormone deficiency
}

\author{
G V VIMPANI, A F VIMPANI, G P LIDGARD, E H D CAMERON, J W FARQUHAR
}

account for the delayed or missed diagnosis of the condition in girls or children with less severe short stature.

\section{Summary}

Four hundred and forty-nine short children, who were all over 2.5 standard deviations below the mean height for age, were identified by screening the heights of 48221 6- to 9-year-old children in three Scottish cities. Most were screened for growth hormone deficiency (GHD). The prevalence of severe GHD in this sample may have been as high as 1 in 4018, much higher than reported. The findings suggest that present referral patterns may

\footnotetext{
Department of Child Life and Health, University of Edinburgh, Edinburgh EH9 1UB

G V VIMPANI, MB, FRACP, senior research fellow

A F VIMPANI, MB, DOBSTRCOG, research fellow

J W FARQUHAR, MD, FRCPED, reader and consultant paediatrician

Regional Hormone Laboratory, Edinburgh EH1 1ED

E H D CAMERON, PHD, FRIC, laboratory director

G P LIDGARD, BSC, PHD, biochemist
}

\section{Introduction}

The primary objective of the Scottish Survey of Short Stature has been to discover the prevalence of growth hormone deficiency (GHD). Information about the prevalence of this condition is important, as it indicates the likely therapeutic requirements for growth hormone $(\mathrm{GH})$ were all those suffering from this condition being diagnosed.

In this study we defined severe GHD by the following criteria: (a) height over 2.5 standard deviations below mean height for age, $(b)$ height velocity less than 25 th centile for chronological age (over 1 year wherever possible), (c) maximum $\mathrm{GH}$ concentration of $9 \mathrm{mU} / 1$ or less in two or more diagnostic tests. By using artificial stimuli in a radioimmunoassay procedure it is nevertheless possible to miss occasional patients with biological GHD who will respond to treatment with GH despite apparently normal GH levels. ${ }^{12}$ Conversely, some children with low $\mathrm{GH}$ levels under experimental testing are capable of normal growth ${ }^{3}$ or, alternatively, fail to respond to administered human 
GH even in the absence of human GH antibodies. ${ }^{4}$ The limited availability of therapeutic supplies of GH has, however, generally meant that it is offered only to those short children with growth failure who have maximum GH levels less than a somewhat arbitrary $20 \mathrm{mU} / \mathrm{l}$, since most children with values in excess of this are normal. The current policy of the Medical Research Council Human Growth Hormone Working Party ${ }^{5}$ is to treat such children with GH for an initial period of one year. Treatment is discontinued in the absence of accelerated growth.

\section{Survey method}

The heights of 48221 children ( 24670 boys) aged 6 to 9 years who were attending all local authority primary and special schools and most fee-paying schools in Edinburgh, Aberdeen, and Glasgow were screened. Four hundred and forty-nine children with heights 2.5 standard deviations or more below the mean height for age ${ }^{6}$ were identified. The children were all in their second, third, or fourth years of school. They were measured in their classrooms using a Harpenden portable anthrompometer, and the smallest children were then remeasured by one of us (GVV), using the method described by Tanner et $a l,{ }^{6}$ with a wall-mounted Harpenden stadiometer carried in a purpose-built mobile clinic. Eighty-eight per cent of 630 absentees thought by their class teachers to be small were measured on a later visit. There may have been up to nine short children among the small absentees who were not measured.

Permission was sought to undertake a screening test for GHD from the parents of all short children, except for 76 who had an organic basis for their short stature. Four of these had previously been diagnosed as suffering from GHD. Of the 373 children seven had previously been investigated and found not to have GHD. Of the remaining 366,10 emigrated from the survey area before investigation, but two were measured subsequently and are known to have a normal height velocity. The parents of 76 children refused permission. Sixty-six of this group were remeasured, and only 29 had a height velocity less than the 25th centile for chronological age. Further information from the parents of these children suggested a possible genetic or organic basis-for example, low birth weight-in 16 . Thirteen could not offer any adequate explanation. The 280 children outstanding were all screened for GHD. We were thus reasonably confident that an accurate assessment of the GH status could be made in all except $31(6.9 \%)$.

Initial screening for GHD was by an insulin hypoglycaemia test in one child, ${ }^{7}$ an extended glucose tolerance test in four, ${ }^{8}$ and exercise in 275 children. ${ }^{9}$ Two hundred and twenty-seven children had blood sampled 30 minutes from the start of a 10 - to 20 -minute period of cycling against moderate resistance on an exercise cycle as recommended by others, ${ }^{910}$ and 48 had blood collected 30 minutes from the end of a similar period of exercise. Nine children who had low GH levels after exercise also had an extended glucose tolerance test. Most of those who had a height velocity less than the 25th centile for chronological age (measured over 12 months), ${ }^{6}$ GH levels under $10 \mathrm{mU} / \mathrm{l}$, and no alternative explanation for their short stature, then had an insulin hypoglycaemia test. The only exceptions were children whose parents refused consent.

GH determinations were carried out by an automated specific radioimmunoassay using a second antibody separation stage, based on the method of Hunter.11 Batches were set up using a Dual Micro Model Compupet diluter-dispenser (General Diagnostics, William Warner and Co Ltd, Eastleigh, Hampshire) and separated, counted, and computed on a prototype Kemtech instrument based on equipment designed by Professor K D Bagshawe (Kemble Instrument
Co Ltd, Burgess Hill, Sussex). Computation entailed the use of a four-parameter $\log / \operatorname{logit}$ transformation. The assay standard was IRP $66 / 217$, and the lower limit of detection used was $0.56 \mathrm{mU} / 1+0.22$ $(n=32)$, defined as that dose corresponding to a $20 \%$ fall in the binding of tracer observed in zero standards. The within-batch coefficient of variation was $8.5 \%(n=21)$ calculated from determinations on aliquots of four different pools measured at the beginning and the end of each batch run. The mean pool values were $3 \cdot 3,8 \cdot 5,31$, and 134 $\mathrm{mU} / \mathrm{l}$.

The between-assay coefficient of variation of $12.5 \%(n=21)$ was calculated by comparing repeat analysis data-that is,each new batch included three samples chosen randomly from previously analysed batches. The assay also consistently showed a between-batch coefficient of variation of under $10 \%$ in the UK interlaboratory quality control scheme for $\mathrm{GH}$.

A crude social score to assess the extent of any deprivation was assigned to each child. This was based on the criteria of Wedge and Prosser. ${ }^{12}$ One point was scored for the presence of each of the following indices of disadvantage: (a) over five children in the family or only one parent; $(b)$ low income-family receiving supplementary benefit or free school meals; $(c)$ overcrowded housing-family living at a density of over 1.5 people per room. This information was obtained from the parents or guardians at interview.

Height standard deviation scores (SD scores) were calculated as follows:

$$
\frac{x-\overline{\mathbf{x}}}{\mathrm{SD}}
$$

where $\mathrm{x}=$ child's height $(\mathrm{mm})$ and $\overline{\mathrm{x}}$ and $\mathrm{SD}=$ mean and standard deviation appropriate to age and sex. Grouped standard deviation distributions were compared with Student's $t$ test. Confidence limits for the prevalence of GHD were calculated from tables of the Poisson distribution.

\section{Results and comment}

Nine children were found to have maximum GH responses of $9 \mathrm{mU} / 1$ or less during an insulin hypoglycaemia test (table I). The data relating to these children is included in table II. Three children (cases 24,211, and 234) had short stature which could have been accounted for on genetic grounds since their heights fell within the normal range when mid-parental height was taken into account. ${ }^{13}$ One of these (case 234) had a normal bone age as estimated by the methods of Tanner et al. ${ }^{14}$ Another (case 24) had a normal height velocity and on our criteria probably did not have biological GHD.

Four of the 449 children were already known to have GHD, but only one was receiving $\mathrm{GH}$ at the time of the initial height screening. The mean height SD score of these four children $(-4 \cdot 18)$ was less than that of the nine children found during the study $(-3.22)$, but the difference just failed to reach significance $(t=2 \cdot 05 ; \mathrm{DF}=11$; $0.05<\mathrm{P}<0 \cdot 1)$. When the three children who may have been short for genetic reasons were excluded the mean height SD score (--3.4) of the remaining children was not significantly different from that of those already diagnosed $(t=1.61 ; \mathrm{DF}=8 ; 0.1<\mathrm{P}<0.2)$. Twelve-month height velocities were unavailable on four children, but in each case the interval height velocity was not inconsistent with a diagnosis of severe GHD. None of the children was severely disadvantaged, although $22 \%$ of the children studied fell into this category.

Although the diagnosis of GHD is essentially auxanological, ${ }^{4}$ the distinction between severe and partial GHD is essentially biochemical, although the more severely affected children will in general have a more extreme degree of growth retardation. ${ }^{1}$ Centres disagree, however, about the maximum GH levels that are consistent with a diagnosis of severe deficiency, and levels of 6 to $10 \mathrm{mU} / 1$ have been suggested by different workers. ${ }^{1}{ }^{15}$ In table III these differences were

TABLE I-Growth hormone levels during screening test and results of insulin hypoglycaemia test

\begin{tabular}{|c|c|c|c|c|c|c|c|}
\hline Screening test & $\begin{array}{c}\text { No } \\
\text { tested }\end{array}$ & $\begin{array}{c}\text { No }(\%) \text { with } \\
\mathrm{GH} \leqslant 9 \mathrm{mU} / 1 \\
\text { on screening } \\
\text { test }\end{array}$ & $\begin{array}{c}\text { No with } \\
\text { GH }>10 \mathrm{mU} / 1 \\
\text { on extended } \\
\text { GTT }\end{array}$ & $\begin{array}{c}\text { No with } \\
\text { normal height } \\
\text { velocity } \\
(>25 \text { th centile })\end{array}$ & $\begin{array}{c}\text { Parents refused } \\
\text { IHT }\end{array}$ & $\begin{array}{c}\text { No having } \\
\text { IHT }\end{array}$ & $\begin{array}{c}\mathrm{GH} \leqslant 9 \mathrm{mU} / 1 \\
\text { on } \mathrm{IHT}\end{array}$ \\
\hline $\begin{array}{l}\text { Exercise } \\
\text { Modified exercise } \\
\text { Extended glucose tolerance test } \\
\text { Insulin hypoglycaemia test }\end{array}$ & $\begin{array}{r}227 \\
48 \\
4 \\
1\end{array}$ & $\begin{array}{l}43(18.9) \\
33(68.8)\end{array}$ & 4 & $\begin{array}{l}2 \\
2\end{array}$ & $\begin{array}{l}8 \\
2\end{array}$ & $\begin{array}{l}33 \\
25\end{array}$ & $\begin{array}{l}6 \\
3\end{array}$ \\
\hline Total & 280 & 76 & 4 & 4 & 10 & 58 & 9 \\
\hline
\end{tabular}


TABLE II-Auxanological, biochemical, and social data on children with severe GHD

\begin{tabular}{|c|c|c|c|c|c|c|c|c|c|}
\hline $\begin{array}{l}\text { Case } \\
\text { No }\end{array}$ & Sex & $\underset{\text { (years) }}{\text { Age }}$ & $\begin{array}{c}\text { Maximum } \\
\text { GH }(m U / 1) \\
\text { on IHT or } \\
\text { exercise }\end{array}$ & $\begin{array}{c}\text { Height } \\
\text { (SD score) }\end{array}$ & $\begin{array}{l}\text { Height } \\
\text { velocity } \\
\text { (centile) }\end{array}$ & $\begin{array}{c}\text { Chronological } \\
\text { age minus } \\
\text { bone age } \\
\text { (years) }\end{array}$ & $\begin{array}{l}\text { Height SD } \\
\text { score allowing } \\
\text { for parents' } \\
\text { height+ }\end{array}$ & $\begin{array}{l}\text { Triceps } \\
\text { skinfold } \\
\text { percentile }\end{array}$ & $\begin{array}{l}\text { Social } \\
\text { score }\end{array}$ \\
\hline $\begin{array}{l}14^{*} \\
426^{+} \\
239^{*}\end{array}$ & $\begin{array}{l}\mathrm{M} \\
\mathrm{F} \\
\mathrm{M}\end{array}$ & $\begin{array}{l}7 \cdot 15 \\
8 \cdot 09 \\
7 \cdot 18\end{array}$ & $\begin{array}{l}<1 \\
1 \cdot 1 \\
2 \cdot 5\end{array}$ & $\begin{array}{l}-3.7 \\
-2.5 \\
-4.3\end{array}$ & $\begin{array}{c}<3 \text { rd } \\
>97\end{array}$ & $\begin{array}{r}-1.5 \\
2.4 \\
3.5\end{array}$ & $\begin{array}{c}(M 133 \mathrm{~cm}) \S \\
-3.0 \\
<-4.0\end{array}$ & $\begin{array}{l}10-25 \\
25-50 \\
50\end{array}$ & $\begin{array}{l}1 \\
0 \\
0\end{array}$ \\
\hline $\begin{array}{l}278^{*} \\
543 \\
536 \\
259 \\
211 \\
16 \\
234 \\
24 \\
131^{*} \\
533\end{array}$ & $\begin{array}{l}\mathrm{M} \\
\mathrm{F} \\
\mathrm{M} \\
\mathrm{F} \\
\mathrm{F} \\
\mathrm{M} \\
\mathrm{M} \\
\mathrm{F} \\
\mathrm{M} \\
\mathrm{M}\end{array}$ & $\begin{array}{l}8 \cdot 02 \\
9 \cdot 52 \\
9 \cdot 38 \\
7 \cdot 33 \\
7 \cdot 41 \\
7 \cdot 71 \\
7 \cdot 61 \\
8 \cdot 57 \\
8 \cdot 42 \\
8 \cdot 34\end{array}$ & $\begin{array}{l}3 \cdot 0 \\
3 \cdot 4 \\
5 \cdot 7 \\
6 \cdot 2 \\
7 \cdot 6 \\
8 \cdot 4 \\
8 \cdot 4 \\
9 \cdot 0 \\
9 \cdot 3 \\
9 \cdot 5\end{array}$ & $\begin{array}{l}-3.9 \\
-3 \cdot 1 \\
-3.3 \\
-2.9 \\
-3 \cdot 0 \\
-4.9 \\
-3 \cdot 0 \\
-2.5 \\
-4 \cdot 8 \\
-3.8\end{array}$ & $\begin{array}{c}<3 \\
<3 \\
10-25 \\
<3 \\
<3 \\
25-50 \\
<3\end{array}$ & $\begin{array}{r}2.6 \\
2 \cdot 9 \\
3.5 \\
2.3 \\
0.4 \\
2.0 \\
-0.1 \\
1.3 \\
1.0 \\
1.7\end{array}$ & $\mid \begin{array}{c}<-4.0 \\
-3.0 \\
-4.0 \\
-2.7 \\
-1.3(\mathrm{M} 149 \mathrm{~cm}) \\
<-4.0 \\
-1.6(\mathrm{~F} 151 \mathrm{~cm}) \\
-1.4(\mathrm{M} 143 \mathrm{~cm}) \\
<-4.0 \\
-3.3\end{array}$ & $\begin{array}{l}25-50 \\
75-90 \\
50-75 \\
10-25 \\
25-50 \\
25-50 \\
75-90 \\
25-50 \\
50-75 \\
25-50\end{array}$ & $\begin{array}{l}0 \\
1 \\
0 \\
0 \\
2 \\
2 \\
2 \\
1 \\
2 \\
1\end{array}$ \\
\hline
\end{tabular}

*Four patients previously diagnosed, three at Yorkhill Hospital, Glasgow, and one in Edinburgh.

$\ddagger$ Values in parentheses are mothers' $(\dot{M})$ or fathers' $(F)$ heights. $\$$ This child's mother was extremely small and probably had GH deficiency $(\mathrm{GH}<1 \mathrm{mU} / 1$ on screening + Values
test).

TABLE III-Prevalence of severe GHD

\begin{tabular}{|c|c|c|c|c|c|c|}
\hline$\underset{(\mathrm{mU} / 1)}{\operatorname{Maximum}}$ & Total & $\underset{\text { ratio }}{\text { Sex }}$ & $\begin{array}{c}\text { Male } \\
\text { prevalence }\end{array}$ & $\begin{array}{c}\text { Female } \\
\text { prevalence }\end{array}$ & $\begin{array}{c}\text { Total } \\
\text { prevalence } \\
\text { per } 100000\end{array}$ & $\begin{array}{c}95 \% \text { confidence limits } \\
\text { prevalence } \\
\text { per } 100000\end{array}$ \\
\hline $\begin{array}{l}\leqslant 6 \\
\leqslant 7 \\
\leqslant 8 \\
\leqslant 9\end{array}$ & $\begin{array}{c}7 \\
8 \\
10 \\
13 \\
\text { (1 normal height velocity) }\end{array}$ & $\begin{array}{l}1.3 \\
1.0 \\
1.5 \\
1.6\end{array}$ & $\begin{array}{l}1 / 6168 \\
1 / 6168 \\
1 / 4112 \\
1 / 3084\end{array}$ & $\begin{array}{l}1 / 7850 \\
1 / 5888 \\
1 / 5888 \\
1 / 4710\end{array}$ & $\begin{array}{l}14 \cdot 5 \\
16 \cdot 6 \\
20 \cdot 7 \\
27 \cdot 0\end{array}$ & $\begin{array}{r}5 \cdot 8-29 \cdot 9 \\
7 \cdot 2-32 \cdot 7 \\
9 \cdot 9-38 \cdot 1 \\
14 \cdot 4-46 \cdot 2\end{array}$ \\
\hline
\end{tabular}

taken into account when calculating the prevalence of severe GHD, which in this population affected 14.5 to $27 \cdot 0$ individuals per 100000 total population. When the three children whose short stature may have been genetic were omitted the prevalence was 14.5 to 20.7 per 100000 (95\% confidence limits $9 \cdot 93-38 \cdot 07$ per 100000$)$.

We also found 96 children with $\mathrm{GH}$ levels of 10 to $20 \mathrm{mU} / 1$ on screening. When necessary an insulin hypoglycaemia test was performed to determine those with partial GHD, but the diagnostic status of 25 children is still not clear and will be the basis of a later report.

\section{Discussion}

Only four $(31 \%)$ of the 13 children with severe GHD had had their condition diagnosed before the study. Three of those found may have had a simple genetic basis for their short stature and merely responded inadequately to both insulin hypoglycaemia and exercise. ${ }^{16}$ Idiopathic GHD has, however, been described in more than one member of a family, ${ }^{17} 18$ and in a recent review of 208 cases Rona and Tanner $^{19}$ found that $4.5 \%$ of the brothers, $2 \%$ of the fathers, and $1.5 \%$ of the sisters and mothers of affected children also had GHD. Several of the parents in this study were extremely short (table II), but only one mother (of case 14; height $132 \mathrm{cms}$ ) was investigated and found to have undetectable $\mathrm{GH}$ levels during an extended glucose tolerance test.

The parents of five of the six newly diagnosed children in whom genetic factors could be excluded had consulted their general practitioners, but none of the children had been referred for further investigations. The parents of only one child had not been concerned about their child's short stature. None of the children with previously diagnosed GHD were girls, although five of the nine children found with GHD during the study were girls. The sex ratio found $(1 \cdot 0-1 \cdot 6)$ was lower than the overall average of 2.9 reported recently. ${ }^{19}$ Although the numbers are too small to permit any definite statistical conclusion, the findings raise the possibility that GHD may be diagnosed relatively less often in affected girls.

None of the children were severely disadvantaged on the basis of our criteria. Although these may miss the more subtle degrees of deprivation, this was thought unlikely to be a signifi- cant problem in any child at the time of the survey, and thus none could be regarded as examples of psychosocial short stature with concomitant GHD.

Regrettably we have not had the time to extend the study to any of the more sparsely populated rural areas. The prevalence in the three cities does, however, seem to be similar despite considerable environmental differences between them. Clearly severe GHD is more common in this population than in the Newcastle area, where an incidence of 1 case in 30000 has been reported. ${ }^{20}$ Even at the lowest extreme of the confidence limits, GHD was almost twice as common, and may be as much as 11 times more common than this. If anything this figure is more likely to be an underestimate, since the parents of 10 children with low GH levels on exercise refused to allow them to have an insulin tolerance test to confirm the diagnosis. Based on an estimated incidence of one in 6000 births we would expect 125 cases to be found each year in Great Britain. At present about 90 new patients with GHD, with a mean age of $10 \cdot 2 \pm 1 \cdot 1$ years, are being accepted annually for treatment in the Medical Research Council's clinical trial of $\mathrm{GH},{ }^{5}$ but this includes some from Ireland and several children with partial GHD. Only a quarter of these children are aged under 5 years.

Our findings indicate that there are some children in the community who can benefit from therapeutic GH treatment but whose diagnosis is delayed longer than necessary. Some with isolated GHD, and perhaps a less severe degree of growth retardation, may be missed altogether, as others have suspected. ${ }^{19}$ Our results support the recommendations of others ${ }^{21}$ who have urged early referral of children with short stature and suggest that the increased effort necessary is unlikely to be in vain.

We thank Professor J O Forfar, Professor J Hutchison, and Professor A Campbell for their ready co-operation in this study, and Dr W Hamilton and Dr M Fyfe for the use of their hospital facilities. Dr S Pocock of the Medical Computing Group kindly provided statistical support. The skilled technical help of Mrs P B Sanger and Mr K S Nicol is gratefully acknowledged. We also thank the Medical Research Council for their support, and the teachers and parents who made the study possible. Professor J M Tanner, Professor R D G Milner, Dr J M Parkin, and Dr W M Hunter have given invaluable 
advice and encouragement. JWF is in receipt of Medical Research Council project grant No $921 / 690$.

\section{References}

1 Tanner, J M, et al, Archives of Disease in Childhood, 1971, 46, 745.

2 Wise, P H, et al, Archives of Disease in Childhood, 1975, 50, 210.

${ }^{3}$ Saenger, P, et al, fournal of Pediatrics, 1974, 84, 137.

4 Preece, M A, and Tanner, J M, Fournal of Pediatrics, 1977, 89, 334.

5 Preece, M A, 1977, personal communication.

6 Tanner, J M, Whitehouse, R H, and Takaishi, M, Archives of Disease in Childhood, 1966, 41, 454.

${ }^{7}$ Roth, J, et al, Metabolism, 1963, 12, 577.

${ }^{8}$ Hunter, W M, et al, Lancet, 1967, 2, 1271.

9 Buckler, J M H, Acta Endocrinologica, 1972, 69, 219.

10 Lacey, K A, Hewison, A, and Parkin, J M, Archives of Disease in Childhood, 1973, 48, 508 .

${ }^{11}$ Hunter, W M, in Methods of Hormone Analysis, ed H Breuer, D Hamel, and H L Kruskemper. New York, J Wiley and Sons, 1975.
12 Wedge, P, and Prosser, H, Born to Fail ? London, Arrow Books, 1973.

13 Tanner, J M, Goldstein, H, and Whitehouse, R H, Archives of Disease in Childhood, 1970, 45, 755 .

14 Tanner, J M, Whitehouse, R H, and Healey, M J R, A New System for estimating Skeletal Maturity from the Hand and Wrist with Standards derived from the Study of 2600 Healthy British Children, parts I and II. Paris, Centre International de l'Enfance, 1962.

${ }^{15}$ Medical fournal of Australia, 1974, 1, 909.

${ }^{16}$ Penny, R, Blizzard, R M, and Davis, W T, Fournal of Clinical Endocrinology and Metabolism, 1969, 29, 1499.

${ }_{17}$ Poskitt, E M E, and Rayner, P H W, Archives of Disease in Childhood, $1974,49,55$.

18 Rimoin, D L, Merimee, T J, and McKusick, V A, Science, 1966, 152 1635.

19 Rona, R J, and Tanner, J M, Archives of Disease in Childhood, 1977, 52, 197.

${ }^{20}$ Parkin, J M, Archives of Disease in Childhood, 1974, 49, 904.

${ }^{21}$ Tanner, J M, Health Trends, 1975, 7, 61.

\title{
Antibodies against BCG antigen 60 in mycobacterial infection
}

\author{
M HARBOE, O CLOSS, B BJORVATN, G BJUNE
}

British Medical fournal, 1977, 2, 430-433

\section{Summary}

A sensitive specific radioimmunoassay was developed to measure antibodies against BCG antigen 60, a prominent antigenic component of BCG bacilli which cross-reacts with similar components in many mycobacterial species including Mycobacterium leprae and $M$ tuberculosis. $A$ lepromatous serum pool had anti-BCG-60 activity with a titre of $10^{5}$ and the tuberculoid pool a titre of $10^{4}$. Testing of individual sera showed striking variations within groups of patients with lepromatous and tuberculoid leprosy. In five of the 20 tuberculoid leprosy sera the anti-BCG-60 activity was above the median for the lepromatous group. The current view that antibody formation against mycobacterial antigens is very low in tuberculoid leprosy thus no longer appears to be tenable. Sera from eight patients with active pulmonary tuberculosis also showed a striking variation in anti-BCG-60 content, and the median value of this group was even higher than in those with lepromatous leprosy.

\section{Introduction}

Leprosy is an example of a "spectral" disease-that is, one that shows considerable variations in clinical course. ${ }^{1-5}$ The current

University of Oslo, Institute for Experimental Medical Research, Ullevaal Hospital, Oslo 1, Norway

M HARBOE, MD, professor of medicine (immunology)

O CLOSS, MD, immunologist

Armauer Hansen Research Institute, PO Box 1005, Addis Ababa, Ethiopia

B BJORVATN, MD, immunologist (present address : Department of Clinical Microbiology, Central Hospital, 4600 Kristiansand S, Norway)

G BJUNE, MD, immunologist (present address: Institute for Experimental Medical Research, Ullevaal Hospital, Oslo 1, Norway) view is that polar lepromatous leprosy is characterised by lack of cell-mediated immunity towards Mycobacterium leprae, apparent uninhibited growth of the bacilli, and a high serum content of antibodies against various mycobacterial antigens. In the highly resistant form, tuberculoid leprosy, the reverse is the case: cellular immunity and hypersensitivity are well developed whereas antibodies to mycobacterial antigens occur infrequently and in low concentration.

Crossed immunoelectrophoresis (CIE) has shown that several mycobacterial species contain more than 40 different antigenic components. $^{6-9}$ To gain more insight into the immunology of leprosy and other mycobacterial diseases there is a great need for additional information on the immune response of the host against individual antigenic components of the mycobacteria.

Antigen 60 is a prominent antigenic component of BCG bacilli which cross-reacts with similar components in many mycobacterial species, including $M$ leprae and $M$ tuberculosis. We have produced monospecific antibodies against this antigen and have developed a specific radioimmunoassay (RIA) for measuring anti-BCG-60 antibodies in rabbit sera. ${ }^{10}$ We report here our studies of anti-BCG-60 antibodies in sera from patients with lepromatous and tuberculoid leprosy and from several groups of controls, including patients with active pulmonary tuberculosis. The results obtained represent a challenge to the simplistic immunological model of leprosy outlined above.

\section{Patients and methods}

Purification and labelling of BCG antigen 60 by electrolytic iodination has been described in detail elsewhere. ${ }^{10}$ The preparation was tested as shown in fig 1 . A mixture of $5 \mu \mathrm{l}$ of concentrated culture fluid obtained after cultivating BCG bacilli for four weeks on Sauton's medium and $5 \mu \mathrm{l}$ of labelled antigen 60 were placed in the circular well and tested by CIE. The top gel contained $200 \mu \mathrm{l}$ of concentrated antiBCG immunoglobulin (Dakopatts A/S, Copenhagen; lot No 115). The plates were washed, pressed, stained with Coommassie brilliant blue, and dried as described elsewhere. ${ }^{11}$ For autoradiography an $x$-ray film (Kodak RP 14 safety film) was applied directly to the stained glass plate with an exposure time of 18 days. The left part of fig 1 shows the plate after protein staining. The pattern shows over 50 distinct precipitin lines: the line corresponding to antigen 60 is 